\title{
Excesso de liberação de capital produtivo, finaceirização e a mensuração da taxa de lucro na economia dos EUA
}

Excess of productive capital released, financialization, and the measurement of profit rates in the U.S. economy

\author{
Lucas Rodrigues ${ }^{a}$ \\ Marcelo Milan ${ }^{b}$ \\ Ronaldo Herrlein Jr. ${ }^{c}$
}

\begin{abstract}
Resumo: Maldonado Filho (1982) mostra a importância da absorção e liberação de capital produtivo para a transformação dos valores em preços de produção. A liberação do capital aumenta o volume de capital-monetário. Contudo, há um efeito de retroalimentação importante neste processo. O capital na forma monetária pode ser reproduzido como capital portador de juros, criando um ímpeto para a financeirização, que por sua vez modifica a taxa de lucro e a própria dinâmica capitalista. Este artigo propõe a utilização de uma taxa de lucro sobre o patrimônio líquido e seus componentes, estimando-a para o caso dos EUA para o período 1960-2015.
\end{abstract}

Palavras-chave: Excesso de capital; Taxa de lucro; Financeirização; Patrimônio Líquido; Alavancagem.

Classificação JEL: B51, E11, O51

\begin{abstract}
Maldonado Filho (1982) shows the importance of release and tying-up of productive capital in the transformation of values into production prices. The release of capital increases the volume of money capital. However, there is an important feedback effect in this process. Capital in monetary form can be reproduced as interest-bearing capital, creating an impetus for financialization, which by its turn modifies the rate of profit and the capitalist dynamic itself. This article proposes the use of a rate of return on equity and its components, estimating it for the US case for the period 1960-2015.
\end{abstract}

Keywords: Excess of Capital; Profit Rate; Financialization; Net Worth; Leverage.

JEL Classification: B51, E11, O51

\footnotetext{
a Professor da Faculdade de Ciências Econômicas da Universidade Federal do Sul e Sudeste do Pará (FACE/Unifesspa). Email: lucas.rodrigues@ unifesspa.edu.br.

${ }^{\text {b }}$ Professor da Faculdade de Ciências Econômicas e do Programa de Pós-Graduação em Estudos Estratégicos Internacionais da Universidade Federal do Rio Grande do Sul (FCE e PPGEEI/UFRGS). Email: milan.marcelo1@gmail.com.

${ }^{\text {c }}$ Professor da Faculdade de Ciências Econômicas e do Programa de Pós-Graduação em Economia da Universidade Federal do Rio Grande do Sul (FCE e PPGE/UFRGS). Email: ronaldoh@ufrgs.br.
} 


\section{Introdução}

Uma das contribuições mais importantes do professor Eduardo Augusto de Lima Maldonado Filho para a economia política marxista foi enfatizar o fenômeno da absorção e liberação de capital produtivo na transformação dos valores em preços de produção. Este construto mostra que, durante o processo de transformação, na ausência de um sistema de crédito e de acumulação, há liberação de capital constante e absorção de capital variável entre as firmas e setores produtivos. Esta redistribuição de capital tem como uma de suas consequências a mudança na taxa média de lucro da economia. Outro efeito importante é que a liberação de capital produtivo ocorre na forma de capital monetário, que é mantido como fundos de reserva. As passagens a seguir apresentam esta configuração:

[...] uma parte do capital-dinheiro realizado não foi reconvertido de sua forma monetária em capital produtivo e permaneceu sob a forma monetária nas mãos dos capitalistas. À medida que esta liberação de capital constante prossegue, conforme continua o processo de reprodução, uma parte crescente do valor-capital (embora em taxas decrescentes) é acumulada sob forma monetária pelos capitalistas. (MALDONADO FILHO, 1982, p. 80)

[...] aquela parcela do capital constante que não é reinvestida (isto é, reconvertida em capital produtivo) e permanece ociosa em sua forma monetária não pode produzir qualquer valor. (ibidem)

[...] é importante atentar não-somente à transformação do capital variável em mais-valia (ou vice-versa) e a seu efeito na taxa de lucro, mas também dedicar especial atenção à transformação do capital produtivo em capital-dinheiro (em outras palavras, a liberação de capital constante). Se a escala de produção permanece inalterada, então este capital-dinheiro tem que permanecer ocioso (fundo de reserva) nas mãos do capitalista, e portanto, no caso da liberação de capital produtivo, cessa de agir enquanto capital. (ibidem)

\section{E finalmente:}

[...] sob as presentes condições (ausência de sistema de crédito e acumulação), a taxa tem que ser calculada somente sobre o total do capital investido (capital-produtivo), e não sobre o total de capital produtivo mais capital-dinheiro, uma vez que o dinheiro, na condição ociosa, não desempenha qualquer função de capital." (op. cit., p. 81)

Estes fenômenos tratados por Maldonado Filho apresentam importantes desdobramentos potenciais de longo prazo. Além da mudança nos níveis da taxa de lucro, é preciso observar se há mudanças na tendência de queda ao se incorporar a acumulação no modelo. Mais importante, o capital-monetário, na presença de um sistema de crédito, pode induzir à financeirização. E, via efeitos de retroalimentação, pode refletir e modificar não só a dinâmica tendencial da taxa de lucro, mas o próprio cálculo da taxa, pois o capitaldinheiro pode ser acumulado como capital portador de juros e desta forma afetar a acumulação e a distribuição dos lucros, contribuindo para crises. 
De fato, a mais recente grande crise capitalista iniciou importantes debates sobre os fatores que contribuíram para sua ocorrência, e dentre esses a lei da queda tendencial da taxa de lucro surgiu como uma das explicações (KLIMAN, 2011; [s.d]; 2009a). A dimensão eminentemente 'financeira' da crise não justifica ignorar a lei, pelo contrário. Grossman (1972[1929]), por exemplo, já apontava para a existência de uma relação entre baixa lucratividade, expansão financeira, exportação de capital e crises. Apesar de esses três últimos elementos caracterizarem a dinâmica econômica do período neoliberal, a relação dos mesmos com o movimento da lucratividade precisa ser investigada. Um dos fatores que dificultam tal análise, contudo, está relacionado às limitações em se tomar os dados, disponíveis através das estatísticas nacionais, e relacioná-los de maneira direta e coerente com as categorias desenvolvidas por Marx (SHAIKH; TONAK, 1994).

Tais desafios são ainda maiores quando se considera a transformação acelerada, no período recente, da movimentação dos capitais em suas distintas formas. Um aspecto importante nesse sentido é o crescimento da magnitude e da proporção dos capitais em circuitos de valorização financeira no capital total das empresas, fenômeno convencionalmente chamado de financeirização e que, como mencionado, pode refletir uma crescente liberação de capital produtivo dos circuitos de valorização pela exploração direta do trabalho. Tal mudança tem produzido debates não apenas dentro do campo marxista (CIPOLLA et al., 2010; DOMINCZAK, 2014), mas também levanta questões sobre a maneira apropriada de mensuração dos lucros pelos métodos contábeis existentes (BRYER, 2006; LEVY, 2014).

A massa e a taxa de lucro, uma vez que orientam o movimento do capital no espaço e no tempo, devem ter uma manifestação aparente, e essa ocorre através dos métodos contábeis de mensuração. Esses podem ser mais ou menos precisos para indicar a dinâmica da acumulação e mesmo adicionar instabilidades ao sistema econômico, como no caso da mensuração das grandezas a preços de mercado (BOYER, 2007; MILAN, 2012). Uma vez que o lucro é a forma fetichizada de existência do mais-valor, o qual camufla a essência do processo de valorização pela exploração, essa forma aparente de medida pode esconder ainda mais as fragilidades das economias capitalistas e sua tendência às crises.

Assim, a denominada financeirização, com sua capacidade ampliada de magnificar a instabilidade que caracteriza o capitalismo, pode ser explicada em larga medida por uma queima insuficiente de capital produtivo, que é portanto liberado em excesso, durante a crise de lucratividade dos anos 1970-1980 (KLIMAN, 2009b). Esse excesso de capital migrou para a esfera financeira e tornou as recuperações cíclicas, daquela crise e das subsequentes, dependentes de reduções na taxa de juros e do aumento no endividamento das empresas, por um lado, mas ampliou a transformação de capitais produtivos em capitais financeiros por outro.

No entanto, o recurso a esses mecanismos gerou suas próprias contradições, as quais se expressaram, por exemplo, na crise do final dos anos 2000. Ou seja, a grande crise de 2007-08 pode ser entendida como sendo engendrada pelas contradições criadas pela 'resolução' da crise dos anos 1970-1980 (SHAIKH, 2011). Assim, os desdobramentos de longo prazo da absorção e liberação de capitais são importantes, na medida em que a queda 
na taxa de lucro proporciona uma expansão das finanças, que acaba por modificar a repartição de mais-valor entre os capitais, e a própria composição dos mesmos, impactando no cálculo da taxa de lucro.

Esse artigo mostra a importância de se incorporar a expansão da riqueza financeira proporcionada pela liberação de capital produtivo, característica da financeirização, no cálculo da taxa de lucro, enfatizando o papel do patrimônio líquido como mais apropriada medida do valor a ser valorizado. Essa medida de lucratividade permite considerar todas as transformações do capital mencionadas acima.

O trabalho está dividido em quatro seções, incluindo essa introdução. Na segunda seção, são discutidas formas alternativas de cálculo da taxa de lucro e, seguindo Roberts (2012) e Freeman (2013), sustenta-se a pertinência do uso do patrimônio líquido no denominador, método geralmente não empregado pelas análises marxistas sobre o tema. Esse método, argumenta-se, apresenta vantagens significativas sobre os métodos tradicionais, ao refletir não apenas a financeirização nas estratégias de valorização e acumulação, mas também o papel dos empréstimos gerados pelo sistema de crédito na valorização do capital total, além de contribuir para a formação de uma taxa média de lucro que é mais próxima do retorno efetivo sobre os diferentes capitais. A terceira seção mostra empiricamente, utilizando séries de tempo descritivas para o período 1960-2015, que a decomposição da taxa de lucro, calculada utilizando o patrimônio líquido, permite evidenciar os efeitos separados do endividamento e da expansão financeira sobre a lucratividade, assim como os limites para sua expansão. A última seção apresenta as considerações finais.

\section{Medidas Alternativas da Taxa de Lucro}

Como amplamente reconhecido pelos estudiosos do capitalismo, o cálculo da taxa de lucro apresenta grandes desafios e limitações, tanto para a economia burguesa como para a economia marxista, as quais dificultam a formação de consensos e abrem espaço para inúmeros debates (HUSSON, 2010a; 2010b). De fato, existem diferentes métodos para se mensurar contabilmente a taxa de lucro, divergindo do cálculo mais comumente aceito pela economia política marxista e apresentado em Maldonado Filho (1982). Assim, Early (2018) apresenta quatro medidas, sendo elas: retorno sobre ativos, retorno sobre capital próprio, margem de lucro, e retorno sobre capital empregado ${ }^{1}$. Os gráficos a seguir apresentam a trajetória das duas últimas medidas taxas de lucro e também da taxa de lucro sobre capital fixo para a economia estadunidense no período 1960-2015, separando o setor financeiro do não-financeiro em função da ênfase dada por este trabalho ao fenômeno da financeirização.

\footnotetext{
${ }^{1} \mathrm{O}$ capital empregado é dado pela soma do patrimônio líquido mais as obrigações de dívida, isto é, pelo lado direito do balanço patrimonial das empresas (passivo).
} 
Gráfico 1 - Taxa de Lucro: Lucro sobre valor adicionado (margem de lucro) EUA: 1960-2015

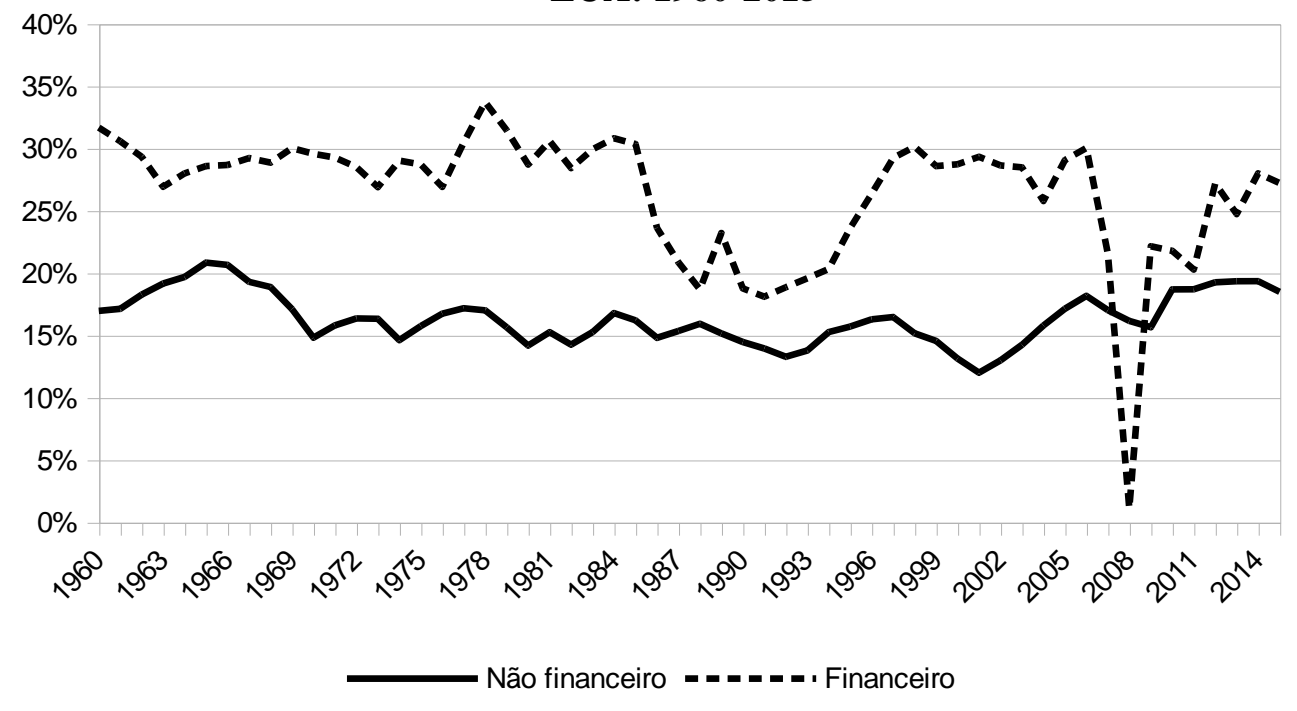

Gráfico 2 - Taxa de Lucro: Retorno sobre capital empregado (ROCE) - EUA: 1960-2015

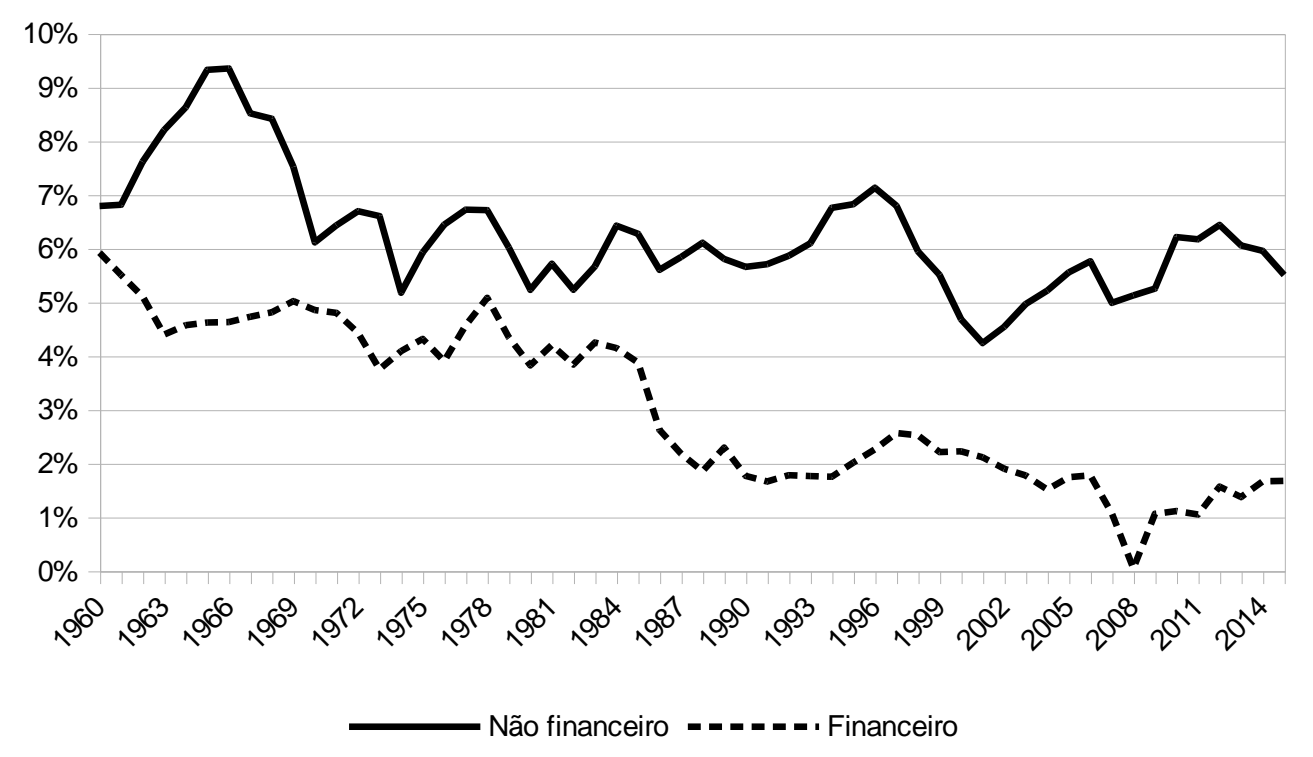




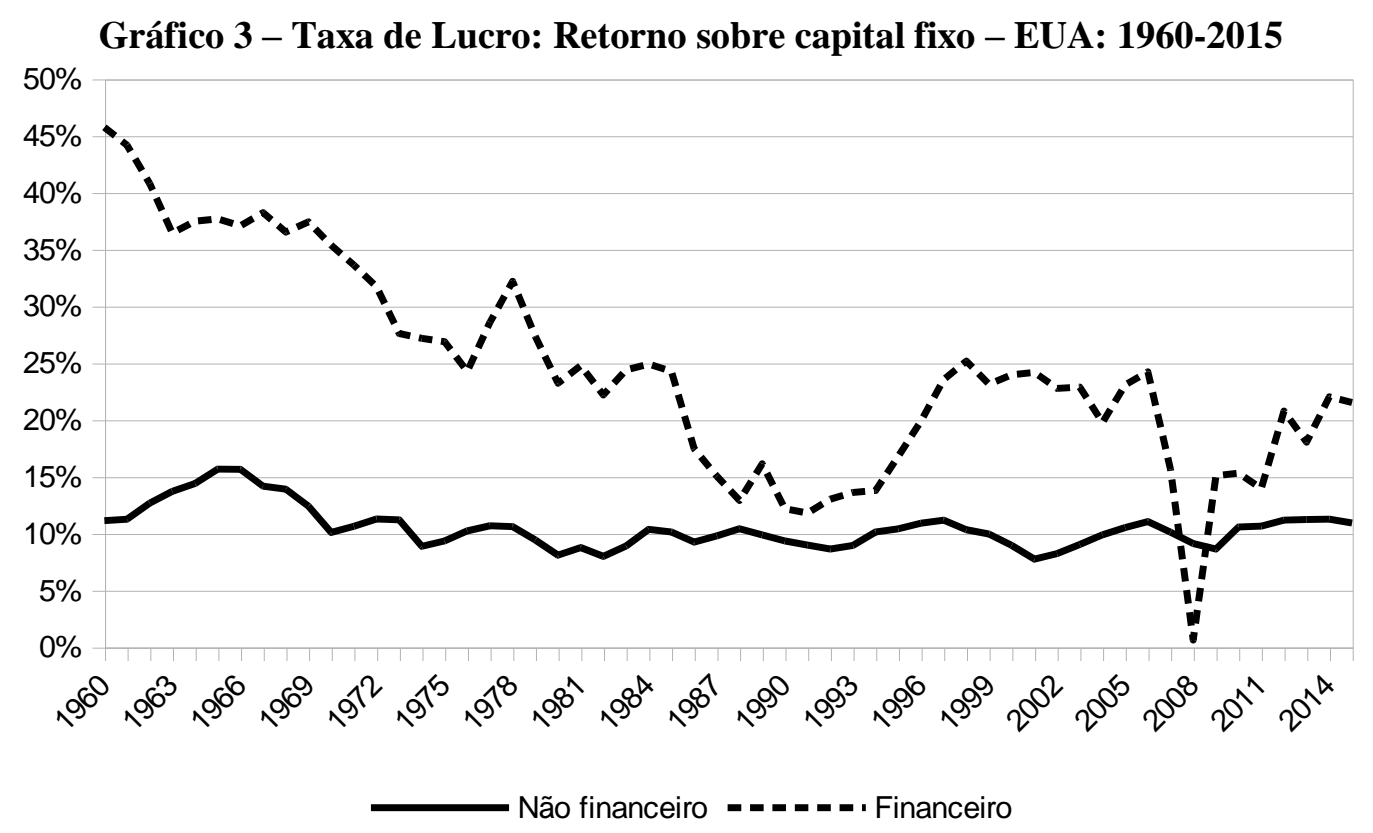

Fonte: Elaboração própria com base nos fluxos de fundos do FED

As dificuldades de cálculo da taxa de lucro são ainda mais ampliadas quando se considera o ritmo acelerado de transformação experimentada pelo capital social total em suas formas de existência nas últimas décadas. No entanto, dada a importância dessa variável para a explicação dos fenômenos econômicos, e principalmente das crises, o desenvolvimento teórico e empírico do estudo da taxa de lucro é uma tarefa que deve ser enfrentada pela economia política marxista.

O crescimento, no balanço das empresas não-financeiras, dos capitais produtivos liberados da esfera produtiva e que se valorizam na esfera financeira via, entre outros, o sistema de crédito, é, talvez, a principal questão a ser considerada pelo pensamento marxista para avaliar os movimentos nos níveis e na tendência da taxa de lucro. A incorporação apenas do capital fixo no cálculo da taxa de lucro (Gráfico 3) pode gerar distorções importantes na análise do comportamento dessa variável (Tabela 1). Isso se dá não apenas devido ao crescimento dos capitais de valorização financeira, mas ao fato de que esses se expandiram de maneira muito mais acelerada que os investimentos em capital fixo ${ }^{2}$. Caso

\footnotetext{
${ }^{2}$ De acordo com os dados do Fluxo de Fundos do Federal Reserve (FED), a relação entre ativos financeiros e ativos não financeiros mantidos pelo setor não financeiros foi mais ou menos constante entre 1945 e 1982, passando de aproximadamente 0,31 para 0,38 nesse intervalo. A partir de então, essa relação apresentou uma aceleração contínua, chegando a 0,96 em 2010.
} 
ambos tivessem variado em proporções iguais, a taxa de lucro calculada considerando apenas o capital fixo e aquela calculada considerando todas as formas de capital sofreria apenas alterações de nível, mas não de trajetória. No entanto, uma vez que a proporção entre capitais financeiros e não financeiros aumentou de modo acelerado, dada a possível intensificação da liberação de capitais produtivos, a trajetória da taxa de lucro muda completamente em cada forma de cálculo, como evidenciado por Freeman (2013).

Segundo Roberts (2012, p. 11), no entanto, a simples inclusão dos ativos financeiros no cálculo da taxa de lucro pode "não ser inteiramente satisfatória, dado que mantém um elemento de dupla contagem" sobre o capital total adiantado. $\mathrm{O}$ autor sugere que o impacto dos capitais financeiros, ou seja, do capital fictício, sobre a lucratividade pode ser mais bem capturado quando se utiliza o patrimônio líquido no denominador da taxa de lucro ${ }^{3}$.

O uso do patrimônio líquido também pode apresentar outras vantagens sobre as demais formas de cálculo da taxa de lucro, pois permite estimar de maneira mais próxima o rendimento obtido a partir do capital próprio dos proprietários e acionistas. Dessa forma, tende a vincular-se de modo mais estreito à acumulação e ao aumento da produção de mercadorias, além de proporcionar uma taxa de lucro que tende à equalização entre os setores, como mostrado abaixo.

É importante enfatizar, como mostram os gráficos 1-3, que a taxa de lucro sobre o total de capitais é estruturalmente distinta entre os capitais financeiros e não financeiros. $\mathrm{O}$ mesmo ocorre com a taxa de lucro calculada apenas sobre o capital fixo (gráfico 3), a qual tende a ser significativamente maior para os setores onde a proporção do capital fixo no capital total é menor, como é o caso do setor financeiro. A tabela 1 ilustra tal distorção por meio de um exemplo numérico:

\section{Tabela 1 - Diferença entre lucro médio e lucro sobre capital fixo entre setores com distintas composições orgânicas}

\begin{tabular}{|l|c|c|c|c|c|c|c|}
\hline Setor & $\begin{array}{c}\text { Capital } \\
\text { Constante } \\
\text { Fixo }\end{array}$ & $\begin{array}{c}\text { Capital } \\
\text { Constante } \\
\text { Circulante }\end{array}$ & $\begin{array}{c}\text { Capital } \\
\text { Variável }\end{array}$ & $\begin{array}{c}\text { Mais- } \\
\text { Valia }\end{array}$ & $\begin{array}{c}\text { Taxa } \\
\text { média } \\
\text { de lucro }\end{array}$ & $\begin{array}{c}\text { Massa } \\
\text { de } \\
\text { Lucro }\end{array}$ & $\begin{array}{c}\text { Taxa de Lucro } \\
\text { sobre Capital Fixo }\end{array}$ \\
\hline A & 50 & 25 & 25 & 25 & 0.375 & 37.5 & 0.75 \\
\hline B & 25 & 25 & 50 & 50 & 0.375 & 37.5 & 1.50 \\
\hline
\end{tabular}

Fonte: Elaboração própria.

\footnotetext{
${ }^{3}$ Roberts (2016 p. 100, tradução própria) argumenta ainda que "Podemos medir o impacto do capital fictício na lucratividade se medirmos o lucro em relação ao patrimônio líquido das empresas, e não apenas seus ativos tangíveis. Inclui passivos financeiros (empréstimos de bancos, títulos e ações emitidas (We can measure the impact of fictitious capital on profitability if we measure profit against the net worth of companies, and not just their tangible assets. This incorporates financial liabilities (loans from banks, bonds and shares issued)".
} 
Seguindo as exposições de Marx (1986) e de Maldonado Filho (1982) sobre a formação de uma taxa média de lucro, magnitudes iguais de capital tendem a se apropriar de uma mesma massa de lucro, independentemente de sua composição entre capital constante e variável. No exemplo acima, considerando que a massa de mais-valor total produzida (MV) é igual a $\$ 75$ e o capital social total adiantado (K) é igual a $\$ 200$, a taxa média de lucro (MV/K) é de 37,5\%. Dessa forma, cada capital de magnitude igual a $\$ 100$ irá se apropriar de uma massa de lucro igual a $\$ 37,5$. No entanto, uma vez que a distribuição entre capital fixo e circulante é determinada por diferenças técnicas em cada setor, as quais não guardam relação necessária entre si, não existe nenhum mecanismo que leve à equalização das taxas de lucro calculadas apenas sobre o capital fixo. A desconsideração dos demais componentes do capital total leva, assim, a diferenças tanto no nível da taxa média de lucro como naquelas que vigoram em cada setor. No exemplo acima, a taxa média de lucro levando em conta apenas o capital fixo seria igual a 100\%. Porém, essa taxa não vigoraria em nenhum dos setores. Aquela vigente nas empresas do setor A seria e de $75 \%$ e em B de $150 \%$.

Segundo Norfield (2016), essas diferenças fazem com que não exista nenhuma base de comparação para a lucratividade entre o setor não financeiro e o financeiro:

\begin{abstract}
Comparar os lucros com os ativos fixos de uma empresa é um método, mas este ignora o papel dos ativos financeiros como a principal alavanca para os lucros do setor financeiro. As receitas dos bancos não são baseadas em seus edifícios imponentes, telas de negociação e softwares de comunicação engenhosos. Qualquer versão de 'capital fixo e circulante' adiantada pelo banco terá pouca relação com a capacidade do banco de gerar retorno. Esta é uma diferença estrutural entre os dois conjuntos de capitalistas, baseada na posição especial dos bancos no sistema monetário. Não há mecanismo para equalizar a taxa de lucro entre os dois setores porque não há uma base sensível para comparar a taxa de lucro de um produtor de aço ou de uma empresa de varejo com a de um banco. (NORFIELD, 2016, p. 84, tradução própria) ${ }^{4}$.
\end{abstract}

No entanto, a dinâmica da taxa de lucro sobre o capital próprio não parece incorrer nesses mesmos problemas. Dado que essa taxa serve de referência para as decisões de inversão dos capitais pelos seus detentores, sua dinâmica segue a da formação do lucro médio. Os capitalistas que auferem uma baixa taxa de lucro sobre seu capital tenderão a movê-lo para os setores de maior lucratividade, e esse movimento pressionará para a formação de uma taxa média de lucro sobre o capital próprio. A magnitude desse último, representado como valor e independente de sua forma concreta, é a própria base de

\footnotetext{
4 "Comparing profits against a company's fixed assets is one method, but this ignores the role of financial assets as the principal lever for financial sector profits. The revenues of banks are not based upon their imposing buildings, dealing screens and slick communications software. Any version of 'fixed and circulating capital' advanced by the bank will have little relationship to the bank's ability to generate a return. This is a structural difference between the two sets of capitalists, based upon the special position of the banks in the monetary system. There is no mechanism for equalizing the rate of profit between the two sectors because there is no sensible basis on which to compare the rate of profit of a steel producer or a retail company with that of a bank".
} 
comparação. Por sua vez, a decomposição dessa taxa de lucro revela tanto os movimentos de aumento do capital em cada setor quanto o efeito da lucratividade do capital aplicado em suas distintas formas.

Contabilmente, o capital próprio de uma empresa corresponde a seu patrimônio líquido (PL) e é igual à diferença entre o total do ativo (A) e o total do passivo (PS). A taxa de lucro sobre o patrimônio líquido pode ser expressa da seguinte maneira, em que P são os lucros:

$$
r p l=\frac{P}{P L}=\frac{P}{A} * \frac{A}{P L}=R O A * \text { Alavancagem }
$$

O termo lucro ou retorno sobre os ativos (ROA, sigla em inglês) indica a taxa de lucro sobre as várias formas em que se encontra o capital total investido de uma empresa ou setor (HAGEL, 2013). Essa variável se assemelha à taxa de lucro calculada por Freeman (2013). A razão entre os ativos totais e o patrimônio líquido, por sua vez, serve de indicador do nível de alavancagem, dado que um aumento nessa relação expressa que parte da aquisição de ativos foi financiada por capital de terceiros ${ }^{5}$. $\mathrm{O}$ impacto positivo do uso do capital de terceiros sobre a taxa de lucro sobre o patrimônio líquido se explica porque ela permite um aumento na massa de lucro apropriada por um capitalista individual sem um aumento correspondente do capital próprio investido pelo mesmo.

\section{A Decomposição da Taxa de Lucro sobre Capital Próprio e sua Avaliação Empírica}

A partir da decomposição indicada no fím da seção anterior, é possível analisar empiricamente o movimento da taxa de lucro sobre o patrimônio líquido e o de seus elementos constitutivos. Os dados do fluxo de fundos do FED permitem que essa análise seja feita, para os EUA, para os setores corporativos não financeiro e financeiro. Por sua vez, tal decomposição permite fazer inferências em relação aos impactos da expansão dos ativos - em especial os financeiros -, da taxa de juros e do endividamento - e portanto do capital-monetário liberado e acumulado na forma de capital portador de juros - sobre os limites da expansão da rentabilidade sobre o patrimônio líquido.

Começando com o setor corporativo não financeiro, o Gráfico 4 apresenta o movimento da taxa de lucro sobre o patrimônio líquido para os EUA entre 1960 e 2015. Três períodos principais podem ser observados. O primeiro, entre meados da década de

\footnotetext{
${ }^{5}$ Outra medida de alavancagem utilizada nas análises financeiras das empresas é a razão dívida sobre receitas (debt to income ratio). A correlação entre essa medida de alavancagem e aquela dada pela razão total de ativos sobre patrimônio líquido é alta para o setor corporativo não financeiros dos EUA, sendo o $\mathrm{R}^{2}$ igual a 0.68 para o período entre 1960 e 2015.
} 
1960 e início dos anos 1980, foi marcado por uma queda contínua da taxa, culminando com a crise de 1970-1980. O segundo, de 1982 a 1996, apresenta uma trajetória de recuperação da lucratividade. O terceiro período, a partir de 1997, é marcado por uma queda brusca da rentabilidade até a crise de 2001 e posteriormente por uma recuperação instável, mantendose no nível dos anos turbulentos de meados de 1970-1980. A tendência de variação do valor adicionado do setor privado não agrícola, obtida via regressão com linha de melhor ajuste (patrimônio de grau 6), manteve, nos três períodos, uma correspondência acentuada com o movimento da taxa de lucro calculada a partir do patrimônio líquido.

Gráfico 4 - Taxa de lucro sobre patrimônio líquido do setor corporativo nãofinanceiro (eixo da esquerda) e tendência (polinômio de grau 6) de variação anual do valor adicionado do setor privado não agrícola (eixo da direita) - EUA: 1960-2015

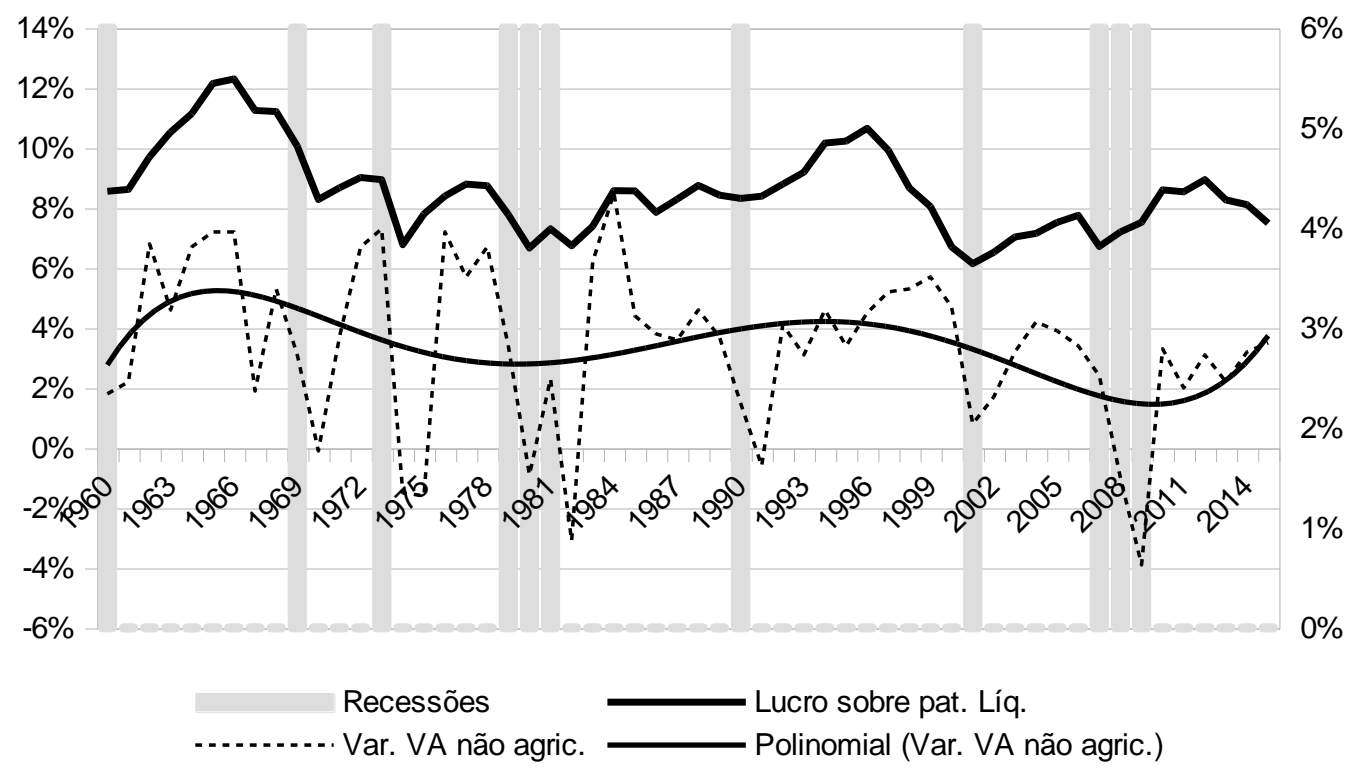

Fonte: Elaboração própria a partir de dados do fluxo de fundos do FED, BEA e NBER.

Nota: As áreas sombreadas representam anos com recessão (pelo menos seis meses de recessão). 
Como para períodos longos a inflação também pode distorcer os valores, o Gráfico 5 apresenta a taxa de lucro sobre capital próprio tanto a custos históricos quanto a custos correntes, apenas para o setor não financeiro, uma vez que os dados a custos históricos não estão disponíveis para o setor financeiro ${ }^{6}$. De fato, no intervalo de alta inflação causada pelos choques do petróleo, as duas medidas diferem. Dado que o tempo de rotação dos ativos financeiros é muito mais acelerado que em comparação ao capital fixo, sua incorporação no cálculo da taxa de lucro tende a minorar as diferenças entre a taxa de lucro a custos históricos e a custos correntes.

\section{Gráfico 5 - Retorno sobre capital próprio do setor corporativo não-financeiro a custos históricos e a custos correntes - EUA: 1960-2015}

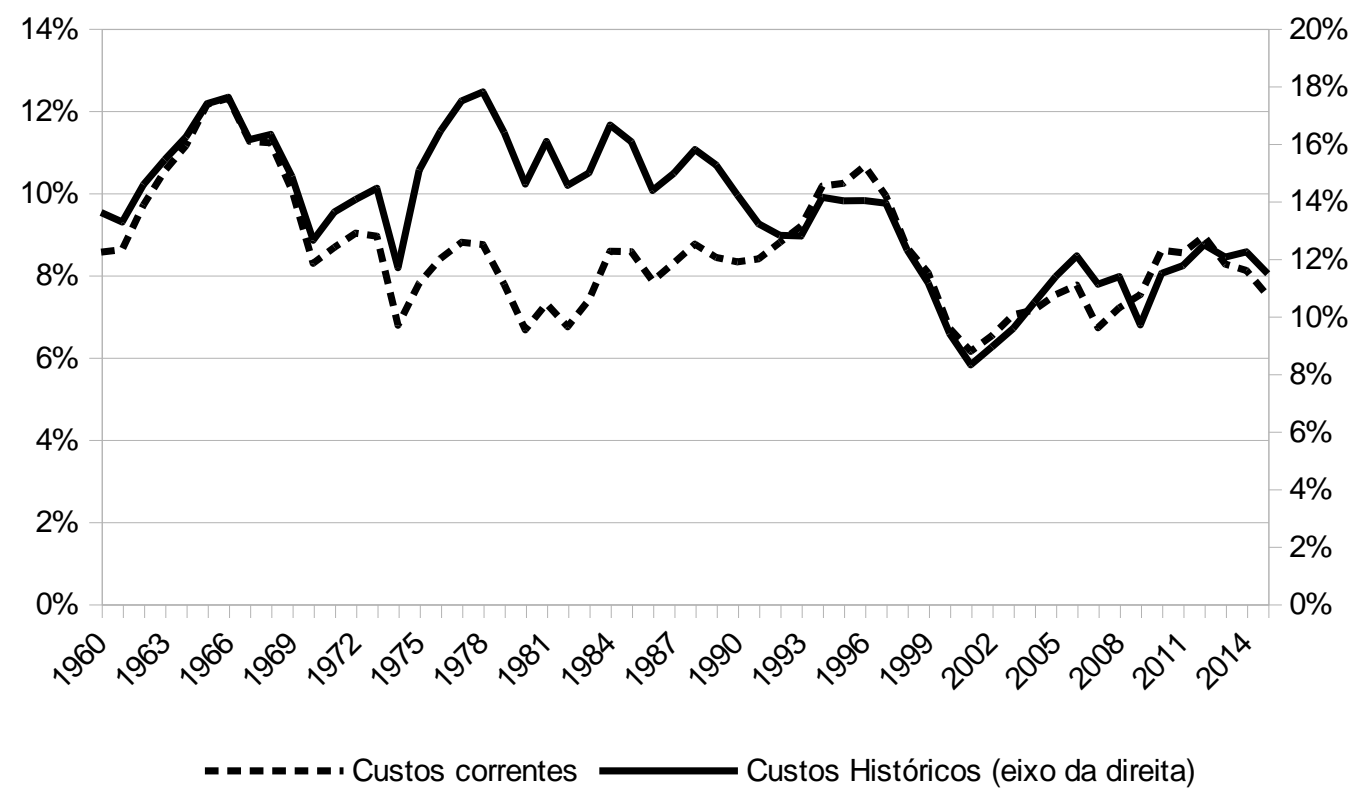

Fonte: Elaboração própria com base nos fluxos de fundos do FED.

\footnotetext{
${ }^{6}$ Os dados de fluxo de fundos FED apresentam o patrimônio líquido tanto a custos históricos quanto a custos correntes. No entanto, a construção dessa variável a custos históricos considera apenas os ativos não financeiros, enquanto os ativos financeiros são tomados a custos correntes. Apesar de os níveis da taxa de lucro, quando utilizadas cada uma dessas variáveis no denominador, apresentarem-se distintos para todo o período, seus movimentos diferem apenas entre 1974 e 1990, podendo tal diferença ser atribuída ao aumento da inflação nesse período. Dada a similaridade nos movimentos das taxas de lucro sobre o patrimônio líquido a custos correntes e a custos históricos, em especial no período de interesse desse trabalho, apenas a primeira é considerada nessa seção.
} 
Pode-se, agora, analisar separadamente os fatores que levaram a essa dinâmica na lucratividade do patrimônio líquido. O Gráfico 6 apresenta o comportamento tanto da taxa de retorno sobre ativos (ROA) quanto do nível de alavancagem do setor corporativo não financeiro (eixo da direita). Como observado, o ROA apresenta uma tendência mais ou menos contínua de queda até 1982 , passando a uma recuperação muito lenta entre esse ano e 1997, voltando a cair a partir de então. Portanto, a crise de 2007-2008 não modifica a trajetória estrutural, sendo possivelmente consequência, mas de forma alguma causa, desta segunda. Ela ocorre em um período de recuperação parcial e limitada do retorno sobre ativos, mas já de desaceleração da alavancagem.

A crise dos anos 1970-1980 e seus resultados parecem, assim, ter interrompido a tendência de queda no retorno sobre o total de ativos, mas a queima de capital não parece ter sido suficiente para sustentar um novo período de crescimento dessa variável, gerando excesso de capital liberado para a acumulação financeira. Por sua vez, a alavancagem apresentou um movimento contínuo de aumento entre 1960 e meados dos anos 1990, sendo que, a partir de 1983, essa tendência sofreu importante aceleração. Essa passou a cair a partir de 1994, chegando a um nível de mínimo local no ano de 2007, quando eclodiu a crise. Assim, o colapso não se explica por um excesso de reciclagem de capital-monetário pelo sistema de crédito. Na verdade, a crise anterior, de 2001, apresenta-se como momento de inflexão no movimento dessa variável ${ }^{7}$.

A recuperação na taxa de lucro sobre o patrimônio líquido entre 1982 e 1993 deveuse, assim, inteiramente à expansão da alavancagem dessas empresas. Quando essa perdeu fôlego e passou a se reduzir, a lucratividade caiu bruscamente, até o ponto da crise de 2001. A queda só não foi maior porque o retorno sobre o total de ativos apresentou certa recuperação após esse ano, muito em função da destruição de certos ativos durante a crise do início dos anos 2000 e seu crescimento menos acelerado após esse período ${ }^{8}$.

\footnotetext{
${ }^{7} \mathrm{O}$ patrimônio líquido $(P L)$ é igual ao total de ativos menos o total do passivo $(A-P)$. A alavancagem pode, assim, ser escrita como o total de ativos dividido pelo total de ativos menos o total do passivo: $\frac{A}{P L}$, a qual é sempre maior que 1 quando a empresa detém algum passivo. Dessa forma, sempre que ocorre um aumento nos ativos, seja em sua quantidade, seja em seu valor contábil, o nível da alavancagem tende a cair caso o passivo permaneça constante. No limite, essa relação tenderia a 1. Períodos de formação de bolhas, como aquele vigente no final dos anos 1990, podem levar, assim, à redução nos níveis de alavancagem medidos dessa maneira. Como consequência, uma análise mais detalhada dos determinantes do movimento dessa variável deve focarse tanto no comportamento das variações nos passivos das empresas quanto nos seus ativos e a possibilidade de reduções aparentes devido à formação de bolhas.

${ }^{8}$ De acordo com dados do fluxo de fundos, o total de ativos do setor corporativo não financeiros cresceu $79 \%$ nos seis anos que antecederam a crise de 2001. Nos seis anos posteriores à crise esses cresceram mais lentamente, sendo 51\% maiores em 2007.
} 


\section{Gráfico 6 - Componentes da taxa de lucro sobre patrimônio Líquido do setor corporativo não financeiro - EUA: 1960-2015}

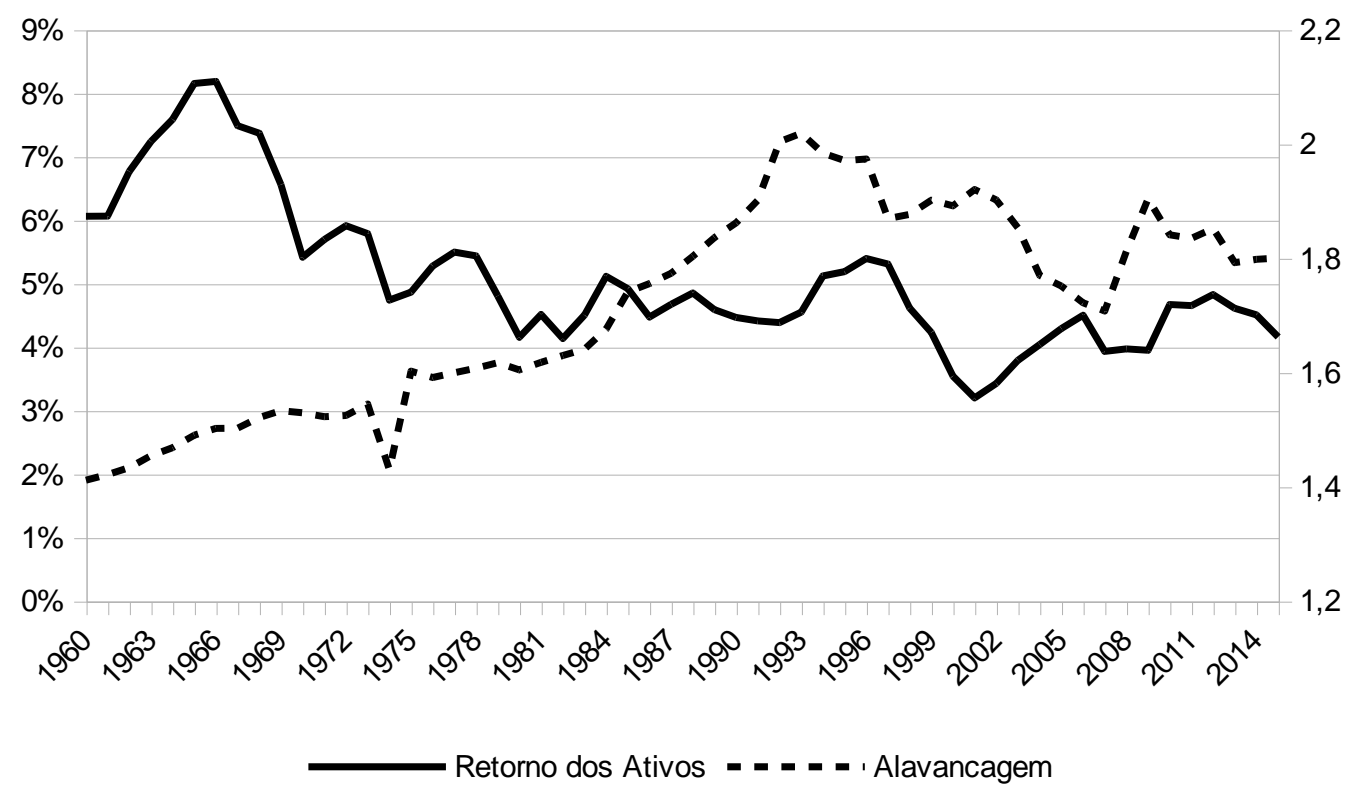

Fonte: Elaboração própria a partir de dados do FED

O aumento da alavancagem também mantém uma relação estreita com a expansão do capital e o retardamento de sua queima. Isso aponta para um importante desdobramento do fenômeno estudado por Maldonado Filho (1982) ao se incorporar o sistema de crédito. Segundo Marx (1986), este sistema possibilita um crescimento da produção para além dos limites que seriam dados apenas pelo capital próprio dos capitalistas. Através do uso do capital de terceiros, é possível que, ao menos por certo tempo, ocorra um descolamento entre o rendimento do capital total investido e o rendimento sobre o capital próprio (GERMER, 1994). Essa elasticidade permite que o processo de acumulação, o qual se reflete contabilmente na expansão dos ativos das empresas, prossiga mesmo quando a lucratividade geral sobre esses é baixa e declinante. Para Marx:

Se o sistema de crédito aparece como a alavanca principal da superprodução e da superespeculação no comércio é só porque o processo de reprodução, que é elástico por sua natureza é forçado aqui até seus limites extremos, e é forçado precisamente porque grande parte do capital social é aplicada por não-proprietários do mesmo, que procedem, por isso, de maneira bem diversa do proprietário, que avalia receosamente os limites de seu capital privado, à medida que ele mesmo funciona. Com isso ressalta apenas que a valorização do capital, fundada no caráter antitético da produção capitalista, permite o desenvolvimento real, livre, somente até certo ponto, portanto constitui na realidade um entrave e limite imanentes 
à produção, que são rompidos pelo sistema de crédito de maneira incessante. O sistema de crédito acelera, portanto, o desenvolvimento material das forças produtivas e a formação do mercado mundial, os quais, enquanto bases materiais da nova forma de produção, devem ser desenvolvidos até certo nível como tarefa histórica do modo de produção capitalista. Ao mesmo tempo o, crédito acelera as erupções violentas dessa contradição, as crises e, com isso, os elementos da dissolução do antigo modo de produção. (MARX, 1986, p. 335, destaque nosso).

O recurso ao endividamento como meio de contornar os problemas de lucratividade sobre o capital próprio é possível, assim, apenas dentro de certos limites. Na medida em que a alavancagem chega a um patamar elevado, os efeitos distributivos adversos desse comportamento restringem seu próprio prosseguimento. Uma das formas em que esse limite se apresenta pode ser verificada na proporção que o pagamento de juros assume em relação à massa de lucro. O Gráfico 7 apresenta essa relação e a compara com o movimento da taxa de juros dos papéis de curto prazo nos EUA. Até o começo dos anos 1980, quando o crescimento da alavancagem era menos acelerado, o pagamento de juros em relação ao lucro acompanhava de maneira estreita as variações da taxa de juros. Porém, a aceleração no endividamento entre 1982 e 1994 levou a um descolamento no comportamento entre essas duas variáveis. Desde então, o impacto dos aumentos da taxa de juros de curto prazo sobre os pagamentos de juros em relação aos lucros foi muito maior que nos anos anteriores. Ao mesmo tempo, a alavancagem respondeu ao aumento do peso dos juros no lucro, reduzindo-se, de maneira mais ou menos defasada, sempre que esses pagamentos atingiram um ponto de máximo.

\section{Gráfico 7: Participação dos juros no lucro operacional líquido e taxa de juros de 3 meses (eixo da direita) - EUA: 1960-2015}

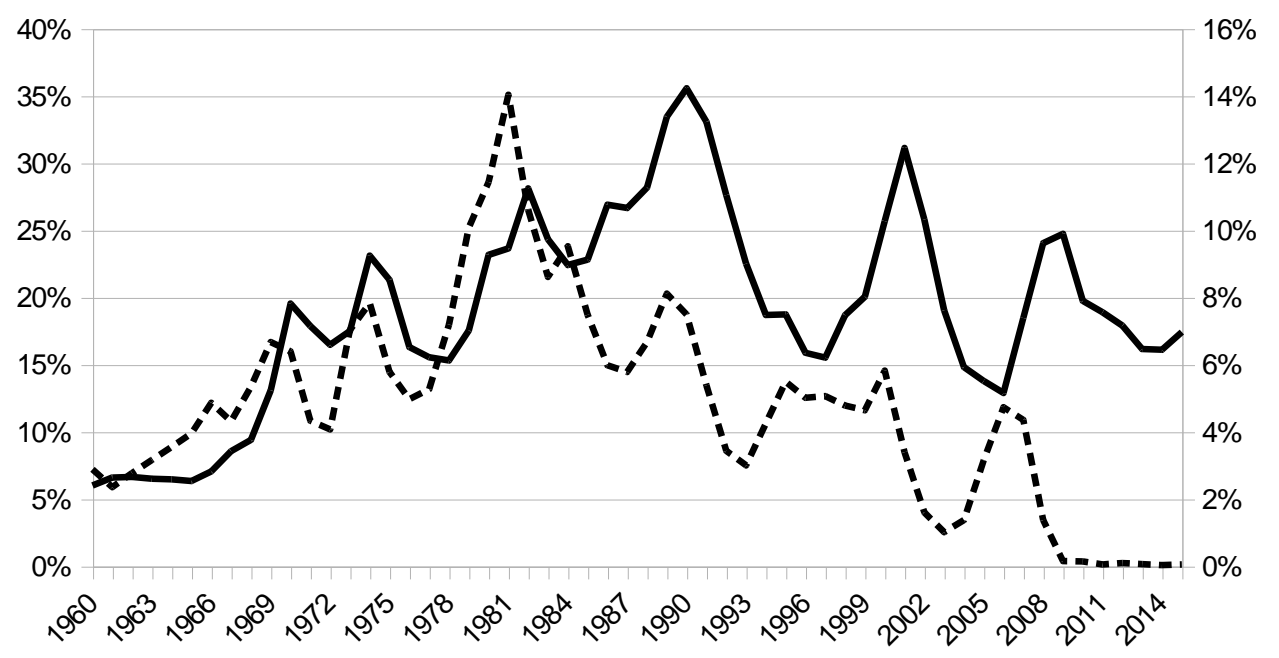

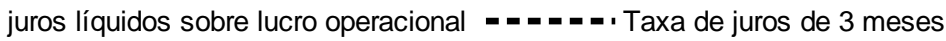


O recurso ao uso do capital de terceiros, na medida em que impulsiona o lucro sobre o capital próprio, possibilita o prosseguimento da acumulação de capital mesmo em bases financeiramente frágeis - o princípio do risco crescente de Kalecki (1937) - . No entanto, novos limites são engendrados, os quais acabam por minar o prosseguimento desse mecanismo e se refletem em uma queda na taxa de lucro sobre o capital próprio. Em última instância, portanto, a recuperação da taxa de lucro depende da queima ou de crescente liberação do capital. A queima tende a ser ainda mais violenta dada a magnitude que o capital assume, inclusive em suas formas financeiras a partir da liberação, devido ao efeito do crédito (ROBERTS, 2016, p. 96-97).

O Gráfico 8 apresenta o comportamento da taxa de lucro sobre patrimônio líquido para as corporações financeiras e não financeiras e para a taxa média para ambos os setores. É importante destacar que a taxa de lucro média é igual a média de cada setor ponderada pela participação de seu patrimônio líquido no total. $\mathrm{O}$ fato de ela seguir de perto a taxa de lucro do setor não financeiro é porque esse responde por uma magnitude muito grande do patrimônio líquido total do setor corporativo.

Inicialmente o comportamento da taxa de lucro para os negócios financeiros não apresenta uma tendência clara de queda, mas é marcada por ciclos sucessivos. Seu movimento é marcado por uma dinâmica inversa daquela do setor não financeiro: nos momentos em que uma apresenta queda a outra presencia recuperação e vice-versa. No entanto, ambas as taxas aparentam gravitar ao redor da tendência linear declinante da taxa média geral de lucro.

Analisando-se o comportamento da taxa de lucro média para os dois setores em conjunto, percebe-se que, dada a participação maior do patrimônio líquido dos negócios não-financeiros no total, o movimento de sua rentabilidade domina o movimento médio. No entanto, a recuperação da rentabilidade média entre os anos 1980 e meados dos anos 1990 é menos pronunciada para o setor corporativo considerado como um todo. Após 1997 essa volta a cair, não sendo capaz de superar os $8 \%$ em nenhum ano a partir de então (KLIMAN; WILLIAMS, 2015). 


\section{Gráfico 8 - Taxa de lucro sobre patrimônio líquido do setor corporativo financeiro, não financeiro e média - EUA: 1960-2015}
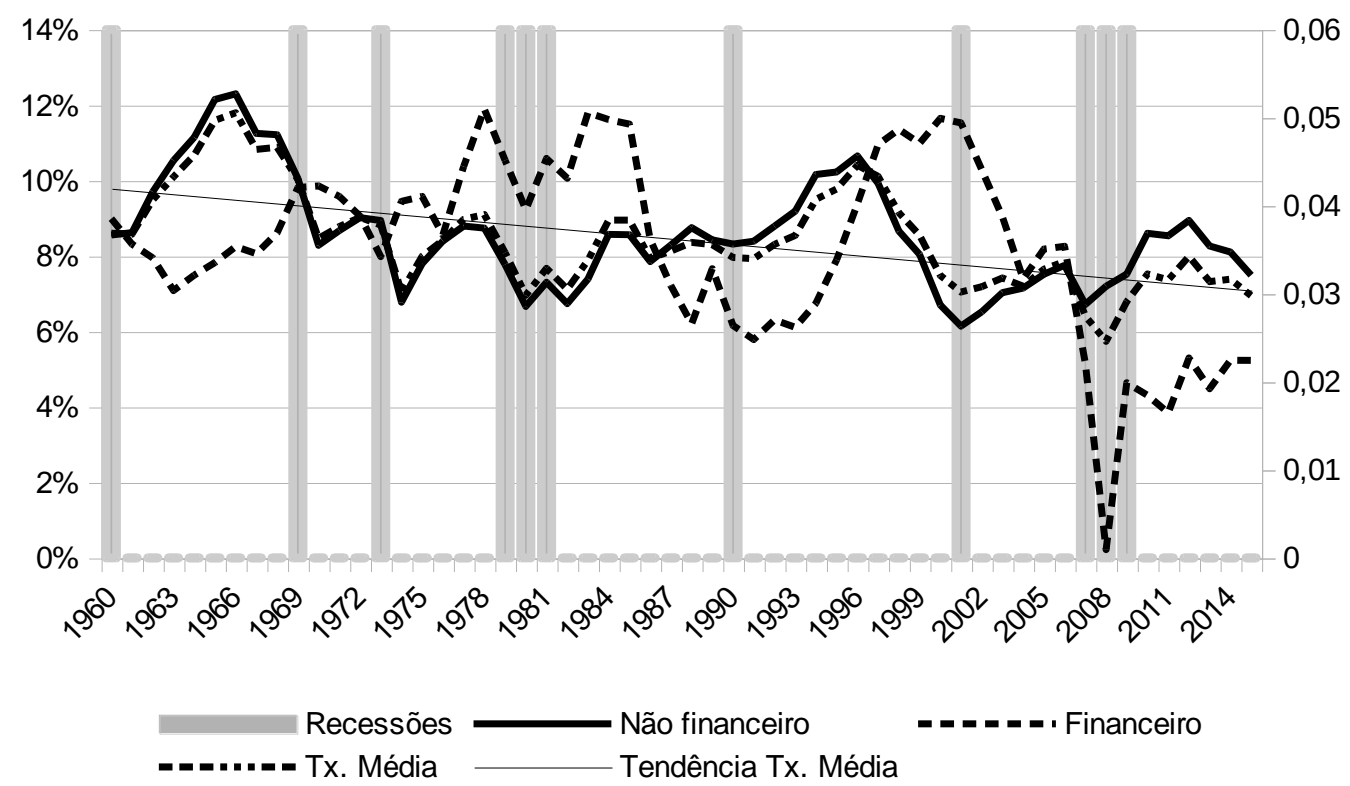

Fonte: Elaboração própria a partir de dados dos fluxos de fundos do FED.

Nota: As áreas cinzas representam anos com recessão (pelo menos seis meses de recessão).

Considerando o setor corporativo financeiro, o movimento de seus componentes indica, por sua vez, um peso muito mais significativo para a alavancagem nesse setor, com um ROA muito baixo. Dada a magnitude elevada de ativos financeiros que esses negócios carregam, a taxa de retorno sobre eles é relativamente baixa se comparado às empresas não financeiras. O ROA desse setor, que vinha mais ou menos constante entre 1960 e o final dos anos 1970, apresentou uma tendência de queda a partir do início da década de 1980, recuperando-se momentaneamente entre 1993 e 1998 (Gráfico 9). O período da crise de 2007-2008 sinaliza o colapso do ROA do setor financeiro.

Por sua vez, a alavancagem cresceu nesse mesmo período, disparando a partir de 1993 até a crise de 2001. A partir de então essa diminui, podendo estar relacionada tanto à formação de bolhas de ativos quanto a reduções no passivo. Com a queda mais acelerada do ROA após a crise das empresas ponto.com, aliada à redução na alavancagem, a taxa de lucro sobre o patrimônio líquido caiu de maneira acentuada no período, atingindo seu nível mais baixo justamente na crise de 2007-2008. 


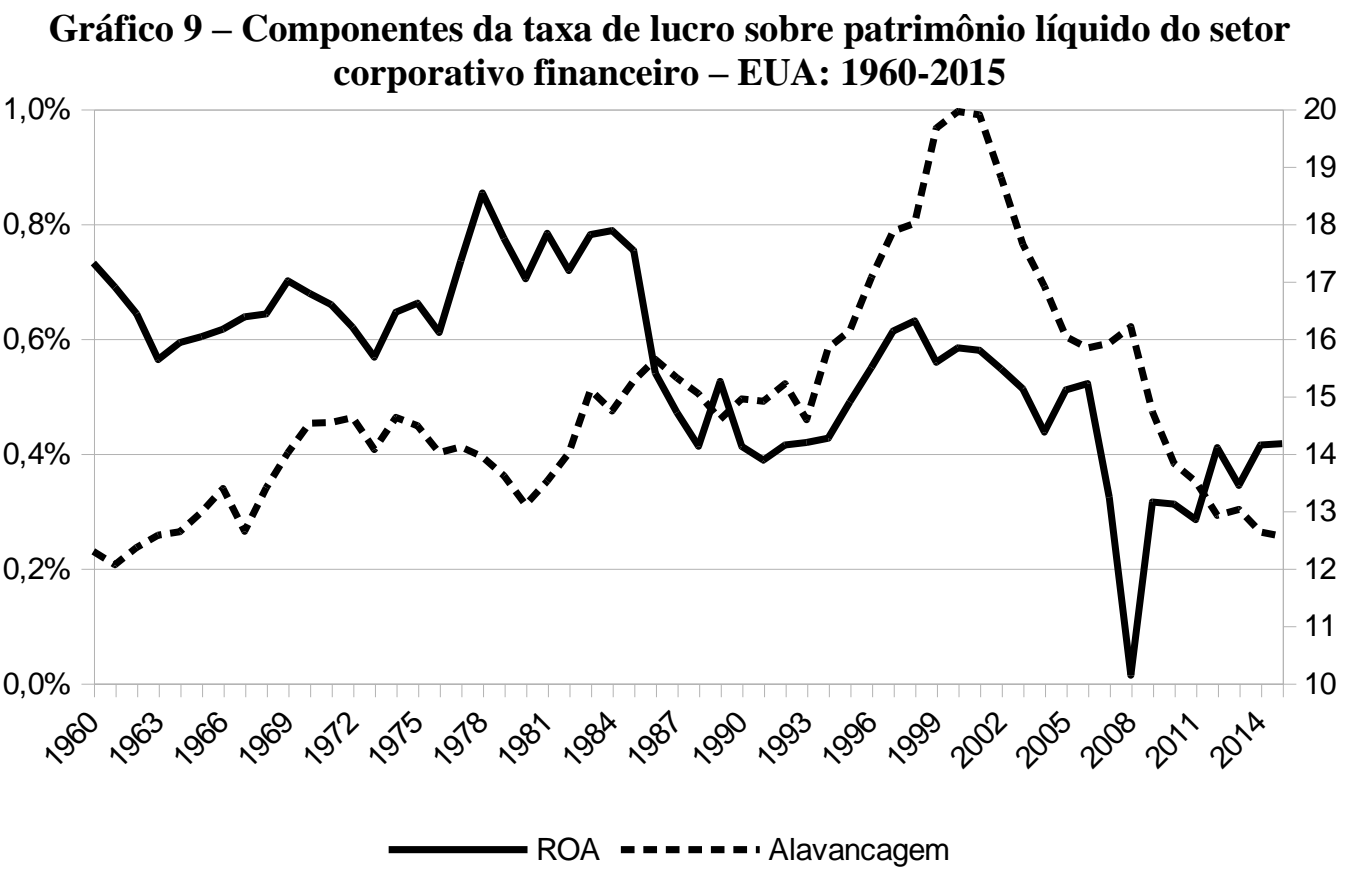

Fonte: Elaboração própria a partir de dados dos fluxos de fundos do FED.

Tomados os dois setores capitalistas em conjunto, o ROA médio foi declinante desde 1960, sem reversão de tendência com a crise dos anos 1970 e 1980 (gráfico 10). Por sua vez, a alavancagem explodiu após esse período, atingindo um teto no final dos anos 1990 e alcançando então um novo patamar, sendo incapaz tanto de seguir sua expansão quando de retroceder de maneira significativa a partir de então.

Dessa forma, na ausência de uma queima de capital profunda, a qual tornasse possível a recuperação do retorno sobre o total de ativos, e dada a aparente dificuldade de expansão da alavancagem, mesmo com a reciclagem dos capitais liberados pelo processo de valorização, a taxa de lucro sobre o patrimônio líquido permanece baixa, sem indicar possibilidades sustentadas de recuperação. 


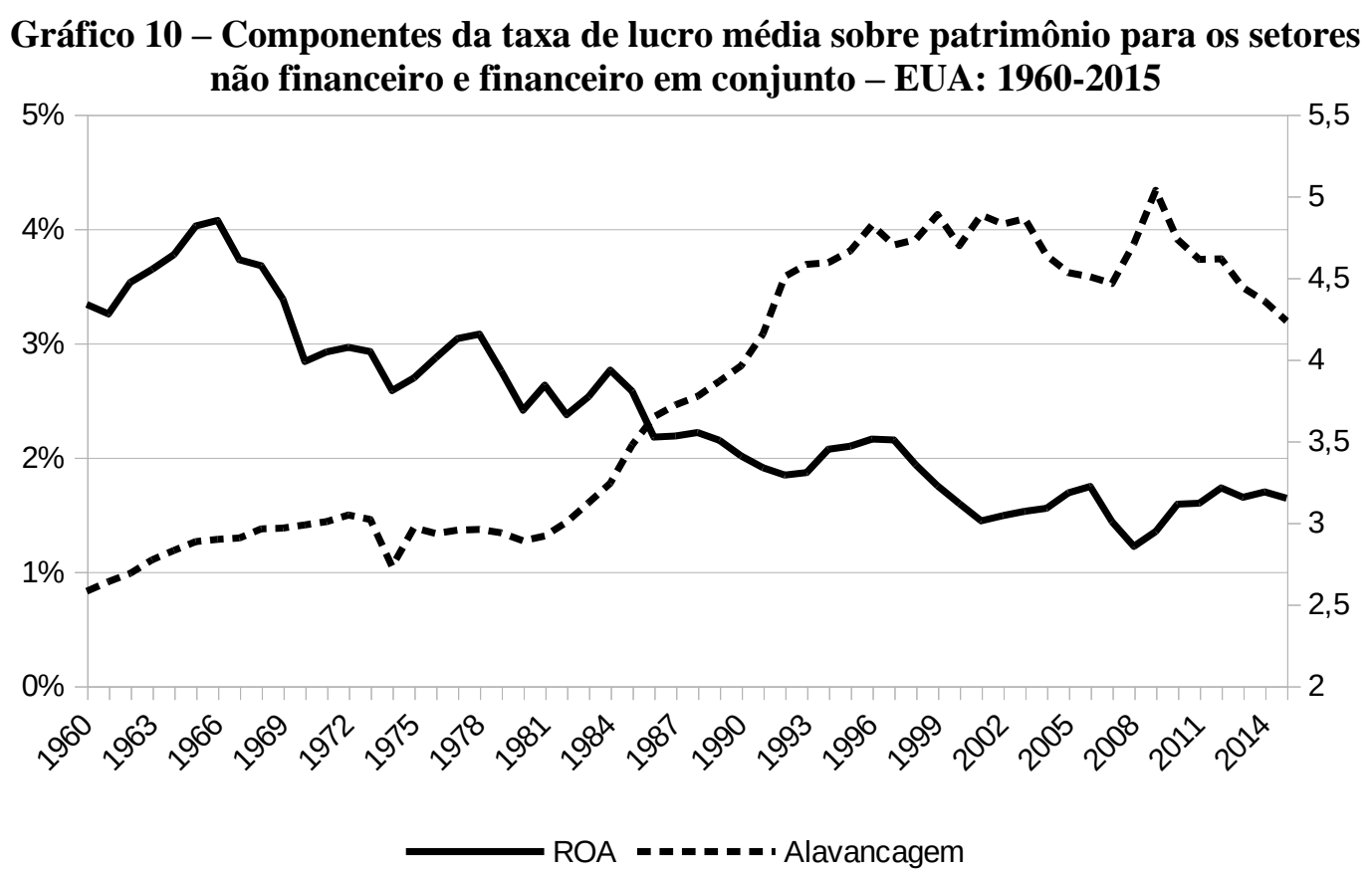

Fonte: Elaboração própria a partir de dados de fluxos de fundos do FED

\section{Considerações Finais}

Os desdobramentos empíricos de longo prazo do fenômeno da absorção e principalmente liberação de capital produtivo se mostram fundamentais para a dinâmica do capitalismo estadunidense (yankee). Como enfatizado por Maldonado Filho (1982), esta redistribuição de capital afeta a taxa de lucro e o montante de capital-monetário no curto prazo. $\mathrm{O}$ aspecto estrutural, contudo, mostra que uma consequência deste fenômeno, na presença do sistema de crédito que recicla o capital-monetário na forma de capital portador de juros, é a financeirização, tanto do ponto de vista dos ativos financeiros das empresas não-financeiras como do ponto de vista do passivo ou dívida destas mesmas empresas. E isso afeta o próprio cálculo da taxa de lucro, pois medida em termos de capital produtivo e não do capital próprio, não permite considerar aqueles mesmos desdobramentos.

Desta forma, a mensuração da taxa de lucro, apesar de sua centralidade no processo de valorização, apresenta inúmeros desafios. Esses aparecem tanto no âmbito contábil quanto nas análises sobre seu movimento tendencial. As sucessivas formas que o capital assume dentro de seu circuito, os diferentes tempos de rotação dessas formas, a proporção em que essas existem em cada período e em cada unidade de acumulação, a velocidade com que são liberados e absorvidos, bem como suas funções distintas, levam à necessidade de um desenvolvimento da mensuração da lucratividade que acompanhe tais mudanças. A expansão financeira das últimas décadas, possível resultado da liberação de capital 
constante do processo de formação de preços de produção é, talvez, a questão mais importante a ser incorporada nessa tarefa.

Nesse artigo foi sugerida uma resposta para essa questão nos exercícios de mensuração da taxa de lucro. Um elemento central são os tipos de ativos que devem ser considerados em seu cálculo. Argumentou-se aqui que o aumento do peso dos ativos financeiros no balanço das empresas capitalistas requer que esses sejam, de alguma forma, incorporados nas mensurações sobre a lucratividade.

Os exercícios empíricos deixam claro o papel que as reduções nas taxas de juros e o aumento no endividamento corporativo tiveram na sustentação da recuperação econômica após a crise dos anos 1970-1980. O artigo mostrou que o recurso ao endividamento por meio dos empréstimos proporcionados pela reciclagem do capital-monetário liberado tornou o processo de acumulação nos EUA mais elástico. Esse possibilitou uma recuperação da taxa de lucro sobre patrimônio líquido mesmo na ausência de recuperação da rentabilidade sobre o total do capital investido. A partir dos anos 1980, esse movimento foi evidente para o setor corporativo não financeiro. No entanto, o recurso à alavancagem para a manutenção de retornos elevados sobre o capital próprio apresenta limites. $\mathrm{O}$ aumento do endividamento potencializa os efeitos distributivos da taxa de juros sobre a proporção dos juros pagos sobre os lucros, os quais tendem a inibir o prosseguimento da alavancagem na ausência de novas reduções nas taxas de juros. Por sua vez, essas reduções têm um efeito negativo sobre a queima de capital e mesmo incentivam sua expansão. Esse processo se expressa na dificuldade de recuperação da rentabilidade sobre o total de ativos, a qual impede uma recuperação sustentada da lucratividade.

Outro resultado importante encontrado foi em relação ao comportamento que o retorno sobre o patrimônio líquido mantém nos setores financeiros e não financeiros. Apesar de apresentarem taxas distintas ao longo do tempo, essas gravitam em torno da tendência declinante de longo prazo, sucedendo-se nos períodos de alta e baixa. Essa gravitação não é encontrada quando se analisa o retorno sobre o total de ativos e o retorno sobre o capital fixo.

Considerando o movimento da taxa média de lucro sobre o patrimônio líquido, percebe-se que os elementos que deram sustentação à sua retomada, até o final da década de 1990, foram se esgotando, o que fez com que essa caísse de maneira acelerada até a crise de 2001, sem recuperação significativa desde então. A alavancagem atingiu um limite nos anos antes da crise das empresas ponto.com, e o capitalismo estadunidense foi incapaz de ultrapassá-lo desde então. Por sua vez, a taxa de retorno sobre os ativos, apesar de mais ou menos estável após 2001, manteve-se em um patamar relativamente baixo, sem capacidade de recomposição. Crises com a de 2007-2008, portanto, devem acontecer com mais frequência se não houver uma recuperação sustentada da taxa de lucro.

Esses fatores indicam a dificuldade para a retomada da taxa de lucro, seja sobre o total de ativos, seja sobre o capital próprio, na ausência de uma queima profunda do capital liberado em excesso no processo de formação dos preços de produção. As taxas de juros atingiram seu patamar mais baixo após a crise de 2007-2008, sendo limitada a possibilidade de uma nova dinâmica de reduções contínuas como se deu a partir de 1982. Por sua vez, o 
excesso de endividamento das empresas tem levado mais a pressões para desalavancagem do que a uma nova rodada de expansão nos débitos.

$\mathrm{Na}$ ausência de queima de capital, mesmo de capital fictício, as saídas propostas para a crise estrutural do capital buscam aprofundar os mecanismos clássicos para a recuperação, quais sejam, aumento da exploração, intervenção dos Estados em favor do capital e exportação de capital, típicos do neoliberalismo. Esses processos também engendram barreiras, sejam elas no âmbito social, político ou geopolítico internacional, como se observa atualmente com a China. Assim, o limite para o capital segue sendo o próprio capital.

\section{Referências}

BOYER, Robert. Assessing the impact of fair value upon financial crises. SocioEconomic Review, [s. 1.], v. 5, n. october, p. 779-807, 2007.

BRYER, Rob A. Accounting and control of the labour process. Critical Perspectives on Accounting, [s. 1.], v. 17, n. 5, p. 551-598, 2006.

CIPOLLA, Francisco Paulo; PINTO, Geane Carolina Rodrigues. Crítica das teorias da financeirização. Revista Sociedade Brasileira de Economia Política, [s. 1.], n. 27, p. 6-28, 2010.

DOMINCZAK, Pedro R. R. Investigando a financeirização pelos seus teóricos. Dissertação (Mestrado em Política Social) - Universidade Federal do Espírito Santo, Centro de Ciências Jurídicas e Econômicas, 2014.

EARLY, James. Profitability Indicator Ratios. Investopedia. Disponível em: < https://www.investopedia.com/university/ratios/profitability-indicator/>.

FEDERAL RESERVE BOARD. Flow of Funds. Disponível em: https://www.federalreserve.gov/RELEASES/Z1/current/default.htm.

FREEMAN, Alan. The profit rate in the presence of financial markets: A necessary correction. Journal of Australian Political Economy, [s. 1.], v. 70, n. 70, p. 167192, 2013.

GERMER, Claus M. O Sistema de Crédito e o Capital Fictício em Marx. Ensaios FEE, [s. 1.], v. 15, n. 1, p. 179-201, 1994. 
GROSSMAN, Henryk. The Law of Accumulation and the Breakdown of Capitalist System: being also a theory of crises. London: Pluto Press, 1992 [1929].

HAGEL, John et al. Success or struggle: ROA as a true measure of business performance. Deloitte University Press, [s. 1.], p. 4-18, 2013.

HUSSON, Michel. The debate on the rate of profit. 2010a. Disponível em: https://internationalviewpoint.org/spip.php?article1894.

HUSSON, Michel. La hausse tendancielle du taux de profit. 2010b. Disponível em: http://hussonet.free.fr/tprof9.pdf

KALECKI, Michel. The principle of increasing risk. Economica, 4 (16), p. 440$447,1937$.

KLIMAN, A.; WILLIAMS, S. D. Why "financialisation" hasn't depressed US productive investment. Cambridge Journal of Economics, [s. 1.], v. 39, n. 1, p. 67-92, 2015.

KLIMAN, Andrew. Roots of the Current Economic Crisis: The Falling-Rate-ofProfit Tendency, Insufficient Destruction of Capital, and Bubbles. 2009a. Disponível

em:

http://www.robinson.cam.ac.uk/postkeynesian/members/ahe/Kliman.pdf

KLIMAN, Andrew. "The destruction of capital" and the current economic crisis. Socialism and Democracy, vol. 23, n. 2, New York, 2009b. DOI: https://doi.org/10.1080/08854300902904741

KLIMAN, Andrew. The Failure of Capitalist Production - Underlying Causes of the great depression. Londres: Pluto Press, 2011.

KLIMAN, Andrew. The Persistent Fall in Profitability Underlying the Current Crisis: New Temporalist Evidence [s.d]. Disponível em: http://akliman.squarespace.com/persistent-fall.

LEVY, Jonathan. Accounting for Profit and the History of Capital. Critical Historical Studies, [s. 1.], v. 1, n. 2, p. 171-214, 2014.

MALDONADO FILHO, Eduardo A. Liberação e Absorção de Capital e a Transformação do Valor das Mercadorias em Preços de Produção. Ensaios FEE, 
v. 2, n.2, p. 73-88, 1982. Disponível em: https://revistas.dee.spgg.rs.gov.br/index.php/ensaios/article/view/134

MARX, Karl. O Capital: Livro III, Vol IV. São Paulo: Nova Cultural, 1986.

MILAN, Marcelo. A Crise Financeira nos EUA: Causas, Consequências e Desdobramentos Teóricos. Revista da Sociedade Brasileira de Economia Política, São Paulo, nº 33, p. 103-145, 2012.

NBER. US Business Cycle Expansions and Contractions. National Bureau of Economic Research. Disponível em: http://www.nber.org/cycles.html.

NORFIELD, Tony. The City. New York: Verso, 2016.

ROBERTS, Michael. Debt matters. 2012. Disponível em: https://thenextrecession.files.wordpress.com/2012/11/debt-matters.pdf.

ROBERTS, Michael. The Long Depression. Chicago: Haymarket Books, 2016.

SHAIKH, Anwar. The first great depression of the 21 st century. Socialist Register, [s. 1.], v. 47, p. 44-63, 2011. 